\title{
Gender Disparity Competence in Drafting Technology among Government Secondary Learning Institutions
}

\author{
Maria Rosario M. Avila, MAED \\ Teofilo Macaso National High School \\ Department of Education, Division of Leyte, Philippines
}

Patricio R. Malquisto, PhD

Eastern Visayas State University Main Campus

Tacloban City, Leyte, Philippines

URL:http://dx.doi.org/10.19044/esj.2019.v15n5p196

\begin{abstract}
This study determined the level of competencies between male and female students in drafting technology as a subject of Grade 8 in secondary schools in Leyte. It assessed the profile of the students along with their age, grade in drafting technology and family income. It also looked into their attitude and study and work habits towards drafting technology. Likewise, it looked into the level of competencies along the different areas such as: Freehand drawing, lettering, geometric construction, orthographic drawing, pictorial drawing, and commercial Arts. The descriptive survey research method was used in this study. It was conducted in selected public secondary learning institutions in Leyte, Philippines with 345 randomly chosen respondents. Structured questionnaires were administered to generate the needed primary data. Findings revealed that majority of the students were 1415 years old with satisfactory rating. They belong to families below poverty threshold. Both male and female students were moderately favourable towards drafting technology and exhibited satisfactory study and work habits. Their level of drafting competency was satisfactory having similar levels of competences for both male and female respondents. Inadequate drafting facilities were the top problems met by the students. In conclusion, both male and female students possessed good competency level in drafting technology course, exhibited moderately favourable attitudes and satisfactory in their study and work habits towards drafting technology. The study recommends that students should improve their attitude and study habits. State of the art facilities have to be provided by the administration to upgrade students' knowledge and skills in drafting technology.
\end{abstract}


Keywords: Gender and development, disparity competence, drafting technology, secondary learning institution

\section{Introduction:}

Acquisition of knowledge, skills and right attitude through education makes a person do better in preparation for his life. Individuals acquired learnings in daily life such as life-long learning. The Philippines needs graduates whose life is full of actions and not just heads full of ideas (De la Rosa et al., 2005). Acquisition of knowledge, information, skills, desirable habits and attitudes through proper education make a person prepare for life (Abocejo and Padua, 2010).

The Director General of Technical Education and Skills Development Authority (TESDA) of the Philippines affirmed that the Technical and Vocational Education and Training (TVET) program of the government is a vital current training prototype which prepare its recipients to a higher learning, intermediary level competence, work and business skills. The addition of two more academic years of senior high school (SHS), to the present 6 years elementary and 4 years secondary program in the Philippines, is another milestone towards producing quality SHS graduates. These additional two years are envisioned to support the specialised and focused learnings of basic education learners, whether on job related courses, composition, fine arts or sports. The program designs and guidelines, instructional materials of some 23 practical occupational sequence will be completed from Grade 7 to 10 (TESDA: New curriculum for K to 12, 2013).

Accordingly, TVET will provide job skills suited to make young Filipinos productive with enhanced technical capacities and their SHS studies relevant to the work place (Cillo, 2011). The TVET is envisioned to boost the complete involvement of home grown enrolees in preparation for their entry into the labour market. Likewise, TVET is geared to introduce manpower services for the improvement of the wealth of the nation. VocationalTechnical (Voc-Tech) education in the Philippines has the primary objective of developing a resilient and approximately skilled middle level manpower equipped with competence supportive to national development.

Implementation of these trainings should be imparted to all individuals regardless of gender based on appropriate societal norms. In essence, females had the right to learn, to have a healthy life, less hard work and, be given the opportunity to participate in political and economic decision making practice to give them a justifiable economic benefits (Abocejo et al., 2012; Guterres, 2017; Abocot and Añonuevo, 2015; Almazan et al., 2018). Voc-Tech education is vital to every student across gender groupings. However, even with the importance of manipulative skills for all students, females tend not to enrol in these courses. Vocational education seems to attract and benefit male 
students in general. Males and female learners have diverse views about technology and take diverse concern of its undertakings and uses (Kalka, 2010).

Gender equality is primary concerns and advocacy by world level vision and targets. The Sustainable Development Goals (SDGs) give a doable worldwide trail to attain this equality. There is a comprehensive global arrangement which sets out a blueprint to end up gender inequality thereby provide equal opportunity as a vital part of the plan (United Nations. 2018).

Throughout the years, TESDA has struggled to lead in the gender categorisation efforts in the TVET division. Sexual characteristics concerns were integrated in TESDA's undertakings as of forecasting, checking and assessment. Growing chances for women to go into non-traditional trades such as automotive and welding trades, among others are the courses offered by TESDA and some other variety of programs for women and men (TESDA, 2012).

Technical drawing in the drafting technology is taken as a distinct subject matter starting from grade 8 to grade 9 as one of the mandated subject in Technical-Vocational high schools (TESDA, 2012). Its competencies are freehand drawing and lettering, geometric construction, orthographic drawing, pictorial drawing and commercial arts (TESDA, 2012). It has been conceptualised on the way to deliver to the students with the basic information and knowledge, positive values and attitude towards work (Abocejo and Padua, 2010).

Drafting is a man's world and drafting technology is a field to be taken by males only (Cillo, 2011). This is based on his study on the competency of drafting technology in secondary schools in Tacloban City where the number of male respondents outnumbered the female counterparts. In this context, it assess the performance of both male and female students in drafting technology subsumed in a competent and gender sensitive environment. There is a need to gauge gender disparity issues to shed light better understanding for those who are planning to enrol in drafting technology as their major field of specialisation at university. Hence, this study hoped to contribute vital information and enlightenment to gender disparity issues within drafting technology among government technical-vocational secondary in learning institutions.

\section{Study Objectives}

This study determined the level of competencies in drafting technology course of male and female grade 8 students among selected secondary learning institutions in Leyte, Philippines. Specifically, it assessed the profile of the students along their age, family income, attitude, study habits and grades in drafting technology course. The various levels of competencies by grade 8 
students along the areas of freehand drawing, lettering, geometric construction, orthographic drawing, pictorial drawing and commercial arts were also studied.

\section{Literature Review:}

Practical and occupational learning was practiced to complete a word denoting to those phases of the instructional procedure concerning manipulative skills in relation to a wide range of instruction (Rodriqguez and Abocejo, 2018). The learning of equipment, machinery plus its allied disciplines, for the attainment of the practical skills, methods and techniques, appreciation and responsiveness regarding to the occupation in the varied areas of profession and industry in the society (Syjuco, 2005, Cuñado and Abocejo, 2018)

The supported practical occupational job related training sequence in the learning unit program was pushed in SY 2007-2008 and has progress in sustaining up, stimulating and promoting practical skills (TVE) in public secondary learning institutions (Rimando, 2012). Practical occupational learning exercises process speaks up to a variety of knowledge which is applicable to the labour domain (Fernandez and Abocejo, 2014). The knowledge conceivably will transpire in a different framework of education (Abocejo and Padua, 2010), including book learning, traditions, as well as work sittings which are enormous transformations among the diverse systems of TVET and their societal perspectives (Norton, 2014).

Meanwhile, TESDA believed that the advancement of an innovative set of program instruction on practical and occupational learning instruction (TVET) education for the learners under the K-12 package can be carried out smoothly with the implementation of the new program, the K-12. The new Tech-Voc curriculum for $\mathrm{K}-12$ is in place in collaboration with the Commission on Higher Education (CHED) and the Department of Education (TESDA, 2013). The three divisions remained functioning very carefully and closely to ensure an effective application of the $\mathrm{K}$ to 12 curriculum. The three organisations combined together to organise around the colleges and institutes as pilot institution for the new 12 year primary and secondary education curriculum (GOP-RA 10533, 2013).

This learning institutions in collaboration with the practical occupational entity of the DepEd constantly delivered the accepted fulfilling institutes of the supported methodological learning sequence with diverse approaches (Abocejo and Padua, 2010), plus package provision in the transfer of instruction and other package services (CHED-DO24, series of 2014). A total of 282-technical-vocational secondary institutes in 16 provinces are implementing the STVEP using the competency-based curriculum [CBC] (Rimando, 2012). 
Of the nation's 282 technical-vocational schools, one hundred fifty seven (157) were considered as skills and vocational schools, eighty (80) as unindustrialised institutes and forty five (45) fishery education institutions (TESDA, 2013). Courses offered in the vocational schools includes automotive mechanics, structure construction, beauty culture, designing, micro- electronics, food and nutrition, fashion wear, machine mechanism, printed circuit tune-up and repair servicing, pipe fitting, cooling system, and metal fusing (Rimando, 2012; TESDA, 2013). Parallel to this, agricultural schools deals with farm crop manufacture, plant production, dairy product and food handling, while the fishery department offers fish seizure and fish handling and canning (Rimando, 2012). Separately, since their own fixed programs presentations, the three (3) different types of technical-vocational (Tech-Voc) institutes have some required subjects like basic computer for the first three years, from grade seven to grade nine (grades 7 to grade 9), and free enterprise on the grades nine to ten of the junior high school [Grades 9 to 10] (Rimando, 2012).

Tech-Voc education necessitates proper attention since the students are expected to be well equipped and at their full potential when they graduate and could be some of them may face the real world of work right away (Rimando, 2012). Hence, implementers should be competent as well. Gender, as one of the issues when it comes to Tech-Voc education should also be considered in training programmes to further improve the situations at hand and to develop equality (Cerbito-Abocot, 2018).

In essence, every educators and staff in unison is working out the programed should be given gender training preparation to avoid categorising and be conscious of societal creation and standard (Abocejo and Gubalane, 2013; Cerbito-Abocot, 2018). As part of increasing experiences, there should be a study of the comparative contributions of young men and women and the equality of resources delivered (Abocejo et al., 2012). One objective should be to encourage each gender's involvement in non-conventional parts (Management and Training Corporation, 2010). Sex involves masculine and feminine feelings, attitudes and manners identification with a precise sexbiologically, psychologically, and socially (Cerbito-Abocot, 2018). When one acts or performs according to commonly shared belief about how males or females are supposed to perform, one adopts a gender (Abocejo et al., 2012; Brym and Lie, 2017).

The Department of Education Regional Office III launched the gender equality movement in schools of Central Luzon (GEMS-CL), the flagship program of Deped Regional Office III which highlights the region's need to revitalise its efforts on Gender and Development (GAD). This project seeks to align with the mandate of the Department to provide students with gender responsive learning environment and various opportunities to understand 
gender roles and eliminate gender inequalities (Abocejo et al., 2012; GEMSCL, 2017).

Notwithstanding with the various philosophical and pedagogical variations the field has experience in the past century, females remain to be hesitant to enrol in technology education courses (Kalka, 2010; TESDA, 2013). Females are less represented in most areas of technology education except in some graphic arts and communication programs (Kalka, 2010). Currently, the labour group welcomes the services of women which was dominantly controlled by men in the past (Abocejo et al., 2012). The office of the technical education stated that in 2013, fifty three per cent of $1,765,757$ practical and job related graduated were women (TESDA, 2013). Most of them were experts in welding and automotive mechanics (Orosa, 2014). The traditional setting of mind in the workplace should begin to accommodate variety of changes to rectitude the ladies for their priceless support to the household and for the constructive influence they have contributed to the general public (Abocejo and Gubalane, 2013; Orosa, 2014).

Regardless of the students' gender, it is a fact that as an individual, everyone is made to be unique and will inevitably face different situations regarding the type of school that will test their attitudes and study habits towards the subjects. Mckay and Hornberger (2009) recommended that in learning institution children come to know their social character in relation to each other and to the institution where they are in (Fernandez and Abocejo, 2014). They also added saying that though schools are not only accountable for instructing the learners, their gender has also differentiated their social roles, they often strengthen the subsidiary role of girls and humans by means of program selections or classroom organisation that will not degrade them (Abocejo et al., 2012).

Interest can be called as an inclination to participate in some kind of activities aside from others. When an individual is interested in a particular activity, one is positively motivated to attend to it and give time for it (Valenzuela, 2015). Thus, interest may play a big role on students' attitude. And according to Ossai (2012), study habits look like to progress with age, and female students had been associated to have a better study habits than males. From situations males and females also have varied interest when it comes to the areas of teamwork and cooperation (Rodriguez and Abocejo, 2018) and young women will often be active in situations that relate to cooperation rather than competition.

The STVEP, has an operational plan to accurately solve the recurring issue of job mismatch, and has intended to deliver for maximum development to the individual armed with practical trade and theoretical skills (Rimando, 2012), appropriate work habits (Abocejo et al., 2012) and appropriate attitudes (Alvarez, Ong and Abocejo, 2017) that will make them financially secured, 
accountable, enduring, dynamic as well as modest and trendy in the workplace (Rimando, 2012).

The TVEP flat form also pursues to train the learners with provable methodological skills in technical, vocational, industrial and other relevant skills to be a fruitful or dynamic citizen of the nation (TESDA, 2013). It also aims to provide secondary education learners with the manipulative ability to perform their academic competence (Rodriguez and Abocejo, 2018) for the qualification certification program. In like manner, this serves to promote and advance the capability of the technical vocational instructors in the transfer of knowledge to the different courses in a way of skills trainings, discussions, and proper studies (Rimando, 2012).

The degree of skills which an individual possesses at a given time is the degree of refinement in his performance. In all types of activities, skills play an important part and they should receive considerations in the educative process (Cillo, 2011). However, females do not take part in skills education tract, they do not enrol in a school which could afford them to high paying job such as Computer Aided Design (CAD), engineering, automotive and information technology (TESDA, 2013). Mostly, only few women are enrolled in science, technology, engineering, and mathematics (STEM) at the tertiary level of education (Scott, 2009).

\section{Theoretical Background and Conceptual Framework}

This study anchored its framework on the feminist existentialism and feminist theory of de Beauvoir (as cited in Hengehold and Bauer, 2017) which emphasised concepts such as freedom, interpersonal relationships, and the experience of living as a human body. "One is not born but becomes a woman" with gender as distinction. This distinction is between biological sex, the social and historical construction of gender and its attendant stereotypes (Mikkola, 2018). The fundamental source of women's expression, Beauvoir notes, is its historical and social construction as the quintessential other (Zalta, 2015). De Beauvoir asserted that women are as capable of choice as men, thus can choose to elevate themselves, moving beyond the 'immanence' to which they were previously resigned and reaching "transcendence", a position in which one takes responsibility for oneself and the world, where one chooses one's freedom.

Many interpret gender as part of the Mother Nature or of one's natural and collective make-up (Abocejo et al., 2012). Essentialists' justifications for gender differences pay no attention to the part of power. Essentialists argue that existing gender behaviour designs help safeguard the existence of the humanity and the even and effective operation of society. The other group of sociologist look up gender dissimilarities as societal consideration, largely of the different social positions occupied by women and men. They look up 
gender as created by group or organisation of social structure and principle (Brym and Lie 2017). "One is not born but becomes a woman" identified as difference, that is, the difference between natural sex and the societal and historical creation of sexual category and its associations (Abocejo et al., 2012; Mikkola, 2018).

In practical learning Dewey (as cited in Carson, 2005) focused his idea of instrumentalism in education on "learning by doing or hands-on learning" which means that the learner should learn not only by theory but also by practical application of what they learn. "Instrumentalism" is a concept of understanding which Dewey formulated in which concepts perceived to be present mainly as tools to answer the problems that come across in the situation (Bhuiyan, 2018).

Attitude which is a non-intellective factor may have a relationship to performance of an individual. In essence, attitudes when properly refined immensely influence the achievement of an individual. The competencies in drafting technology served as the desired objectives for the students including the teachers in drafting. These desired competencies in drafting are expected skills to be developed by both male and female students after they have taken the subject. This study focused on the level of acquired competencies. The level of competencies in drafting technology was traced and looked into whether it significantly relates with the different attributes of students, namely; age, gender, attitude towards the subject drafting, and study and work habits as well as their grades in drafting in grade 8.

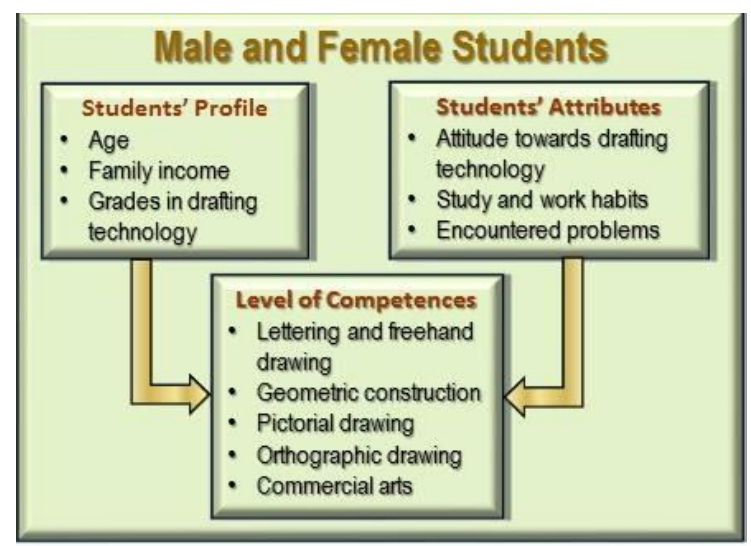

Figure 1. Conceptual Framework of the Study

Figure 1, depicts the conceptual framework of the study which shows the level of competencies acquired in drafting technology by grade 8 secondary learners. It highlights the factors which relate to the level of the competencies in drafting technology including the profile of grade 8 high school students. The male and female students' profile captures the age, family income and grade in drafting technology. Other students' attributes are attitude 
towards the drafting technology, study and work habits and encountered problems. Meanwhile the level of competencies in drafting cover the lettering and freehand drawing, geometrical construction, pictorial drawing, orthographic drawing, geometrical and commercial arts.

\section{Hypothesis}

This study tested the null hypothesis of no significant difference in competencies, attitude, work and study habits between male and female learners in drafting technology.

\section{Research Methodology: \\ Research design and locale}

This study employed a descriptive comparative research design utilising structured questionnaires administered as primary instrument in the data collection. The survey was implemented in three (3) selected secondary learning institutions in the division of Leyte, Philippines. The generated data were process and analysed to serve as bases of interpretations and implications on the advancement in technical drawing course among the 3 study sites. Descriptive and inferential statistics were used to derive the needed summary statistics.

\section{Research respondents}

The respondents of the study comprised 345 Grade 8 learners enrolled in technical-vocational courses in drafting technology from the three (3) selected secondary learning institutions. There were 155 females and 190 males based on the records gathered from each learning institution.

\section{Research instrument}

Two sets of questionnaires were floated; one set for students and the other set was for the teachers. The students' questionnaire were has two parts. Part one (1) of the students' questionnaire, included the personal background of the students in terms of age, sex, school, grade in drafting technology, family income, attitude towards Technical Drawing with nine (9) items, and study and work habits with 10 items. Part two (2) sought the male and female students to reveal the problems they met in Technical Drawing subject with 10 items. Meanwhile, the teacher's questionnaire, with only one part, dealt with the level of competencies of their students.

The questionnaires elicited data on students' levels of prescribed competencies along five (5) areas: (1) Freehand and lettering, which tested the level of competence of the male and female students though their performance in lettering styles, sketching, pencil rendering including the proper use of appropriate instruments; (2) Geometric construction which checked the 
knowledge of the male and female students their ability to use compass and straight edges, differentiate lines, angles, points and polygons; (3) Orthographic drawing which measured the male and female students their ability to visualise things in different views and to construct the different principal views of an object; (4) Pictorial drawing which assessed how good the male and female students identify the different divisions of isometric drawing. It also tests their level of ability to visualise different figures in different angles, draw ellipse form in an isometric views and construct different types of pictorial drawings; and (5) Commercial Arts which measured the ability of the male and female students in designing and making posters, logo, and monogram. Each competency included 10 items each. There were a total of 50 items distributed in the five (5) areas of the subject.

\section{Data gathering procedures}

Prior to the conduct of the study, permission was sought from the schools' division Superintendent. The approved letter by the division Superintendents was showed to the school heads of the selected secondary learning institutions. These schools were all government owned offering technical-vocational courses. The survey instrument was administered by the researchers to the grade 8 students and teachers of drafting technology courses which were later retrieved after they have been answered.

\section{Treatment of data}

After validation of the answered questionnaire, the data were encoded, collated and processed to be ready for analysis. Descriptive and inferential statistical analyses were carried out on the data sets. Weighted mean, percentages, T-test of two independent samples, and correlation analysis were run on the data using a licensed Statistical Package for the Social Science (SPSS).

\section{Discussion Results:}

\section{Profile of grade 8 students}

As reflected in the Table 1, the mean age of the female students is 13.75 or 14 years, which was within the range of the regular age of grade 8 . The mean age of the male students is 14.20 or 14 years. This shows that the grade 8 male and female students were at their regular age for the grade level. Thus, it implies that they are capable of taking the subject drafting technology. 
Table 1. Profile of grade 8 students by gender, age, grade in drafting and family

\begin{tabular}{|c|c|c|c|c|c|c|}
\hline \multicolumn{7}{|c|}{ income } \\
\hline \multirow[b]{2}{*}{ Variable and indicator } & \multicolumn{2}{|c|}{ Female } & \multicolumn{2}{|c|}{ Male } & \multicolumn{2}{|c|}{ Both Gender } \\
\hline & $\begin{array}{c}\text { Fre- } \\
\text { quency }\end{array}$ & $\begin{array}{l}\text { Per- } \\
\text { cent }\end{array}$ & $\begin{array}{c}\text { Fre- } \\
\text { quency }\end{array}$ & $\begin{array}{l}\text { Per- } \\
\text { cent }\end{array}$ & \begin{tabular}{|c|} 
Fre- \\
quency
\end{tabular} & $\begin{array}{l}\text { Per- } \\
\text { cent }\end{array}$ \\
\hline Age & & & & & & \\
\hline 18 years old or older & - & - & 4 & 2.11 & 4 & 1.16 \\
\hline 16 to 17 years old & 5 & 3.23 & 17 & 8.95 & 22 & 6.38 \\
\hline 14 to 15 years old & 84 & 54.19 & 117 & 61.58 & 201 & 58.26 \\
\hline 13 years or younger & 66 & 42.58 & 52 & 27.37 & 118 & 34.20 \\
\hline Total & 155 & 100.00 & 190 & 100.00 & 345 & 100.00 \\
\hline Weighted Mean & \multirow{2}{*}{\multicolumn{2}{|c|}{$\begin{array}{r}13.75 \\
0.81\end{array}$}} & \multirow{2}{*}{\multicolumn{2}{|c|}{$\begin{array}{r}14.20 \\
1.14\end{array}$}} & \multicolumn{2}{|r|}{14.00} \\
\hline Standard Deviation & & & & & & 1.03 \\
\hline \multicolumn{7}{|l|}{ Grade in drafting technology } \\
\hline Outstanding & 25 & 16.13 & 30 & 15.79 & 55 & 15.94 \\
\hline Very satisfactory & 63 & 40.65 & 54 & 28.42 & 117 & 33.91 \\
\hline Satisfactory & 49 & 31.61 & 56 & 29.47 & 105 & 30.43 \\
\hline Fairly satisfactory & 18 & 11.61 & 48 & 25.26 & 66 & 19.13 \\
\hline $\begin{array}{l}\text { Did not meet } \\
\text { expectations }\end{array}$ & 0 & 0.00 & 2 & 1.05 & 2 & 0.58 \\
\hline Total & 155 & 100.00 & 190 & 100.00 & 345 & 100.00 \\
\hline Weighted Mean & \multicolumn{2}{|r|}{84.99} & \multicolumn{2}{|r|}{83.59} & \multicolumn{2}{|r|}{84.22} \\
\hline Standard Deviation (SD) & \multicolumn{2}{|r|}{1.37} & \multicolumn{2}{|r|}{5.50} & \multicolumn{2}{|r|}{5.06} \\
\hline Family income & & & & & & \\
\hline Above PTI & 6 & 3.87 & 15 & 7.89 & 21 & 6.09 \\
\hline Below PTI & 149 & 96.13 & 175 & 92.11 & 324 & 93.91 \\
\hline Total & 155 & 100.00 & 190 & 100.00 & 345 & 100.00 \\
\hline
\end{tabular}

As shown in Table 1, the mean of the final grade of the female group of respondents is about 85 percent which corresponds to a "very satisfactory" rating. The weighted mean of the final grade of the male group of respondents is nearly 84 per cent which corresponds to a "satisfactory" rating. This implies that the learners are performing within the expected range they are supposed to be academically doing. The largest groups of male and female exhibited very satisfactory grades indicative of their commendable performance in drafting technology courses. Meanwhile, female students manifested better grades compared to their male counterparts in drafting technology implying that, may be female students have better study habits than males learners.

Considering family income, majority of the female respondents' families were below threshold family income at 149 accounting 96.13 per cent of the total female respondents. The same holds true for the male respondents' families whose count reached 175 or 92.11 per cent of total male respondents. This scenario evidently showed that students under the study area belong to poor families with only few respondents belonging to families above the poverty income group. 


\section{Attitude towards drafting technology}

The overall findings show that drafting is moderately favourable to grade 8 student respondents with weighted mean of 3.46 (Table 2), the same holds when disaggregated by gender. This may suggests that the attitude of male and female students still exhibit lack of interest towards drafting technology, they may need proper guidance from parents, encouragement and motivation from school teachers. This scenario should uphold the argument put forward by Valenzuela (2015) that any person, once motivated, ever gets interested to engage in a particular activity and will give time to accomplish such an assigned task. On the lighter note, almost half of the female manifested favourable attitude towards drafting technology with a little over one-tenth exhibiting very favourable attitudes. The male group showed smaller proportion of favourable students towards drafting technology at about 45 per cent. Arguably, a slight difference in attitude towards drafting technology course does exist between male and female students. Gender disparity is seen very minimal in terms of the attitude variable assessed in this study. Both male and female groups are moderately favouring the institutionalisation of the drafting technology in their SHS curriculum.

Table 2. Attitude of grade 8 secondary students towards drafting technology

by gender

\begin{tabular}{|c|c|c|c|c|c|r|}
\hline \multirow{2}{*}{ Attitude level } & \multicolumn{2}{|c|}{ Female } & \multicolumn{2}{c|}{ Male } & \multicolumn{2}{c|}{ Both Gender } \\
\cline { 2 - 8 } & $\begin{array}{c}\text { Fre- } \\
\text { quency }\end{array}$ & Percent & $\begin{array}{c}\text { Fre- } \\
\text { quency }\end{array}$ & Percent & $\begin{array}{c}\text { Fre- } \\
\text { quency }\end{array}$ & Percent \\
\hline Very favourable & 18 & 11.61 & 20 & 10.53 & 38 & 11.01 \\
\hline Favourable & 70 & 45.16 & 74 & 38.95 & 144 & 41.74 \\
\hline $\begin{array}{c}\text { Moderately } \\
\text { favourable }\end{array}$ & 60 & 38.71 & 85 & 44.74 & 145 & 42.03 \\
\hline Less favourable & 6 & 3.87 & 11 & 5.79 & 17 & 4.93 \\
\hline Not favourable & 1 & 0.65 & 0 & 0.00 & 1 & 0.29 \\
\hline Total & 155 & 100.00 & 190 & 100.00 & 345 & 100.00 \\
\hline $\begin{array}{c}\text { Mean } \\
\text { (Description) }\end{array}$ & $\begin{array}{c}\mid c \\
\text { (moderately } \\
\text { favourable) }\end{array}$ & $\begin{array}{c}\text { (moderately } \\
\text { favourable) }\end{array}$ & \multicolumn{2}{c|}{$\begin{array}{c}3.46 \\
\text { (moderately } \\
\text { favourable) }\end{array}$} \\
\hline $\begin{array}{c}\text { Standard } \\
\text { Deviation }\end{array}$ & \multicolumn{2}{|c|}{0.581} & \multicolumn{2}{c|}{0.514} & \multicolumn{2}{c|}{0.546} \\
\hline
\end{tabular}

\section{Study and work habits towards drafting technology}

As reflected in Table 3 it showed that the study and work habits of Grade eight female students respondents have a "satisfactory rating" with a mean of 3.46. On the other hand, its counterpart, the male respondents got a rating of 3.32 which is also equivalent to a satisfactory rating. 
The combined group of male and female student respondents had an overall mean score of 3.38 which signifies a "satisfactory" rating. These findings indicate that both gender manifested satisfactory study and work habits towards drafting technology. If the goal is to let them acquire an outstanding study and work habits, then they need to be more motivated along their study and work habits towards their drafting technology course taking into consideration sometimes the inadequacy of tools and training facilities or the learning environment itself.

Table 3. Study and work habits of grade 8 secondary students towards drafting technology

\begin{tabular}{|c|c|c|c|c|c|c|}
\hline \multirow{2}{*}{$\begin{array}{c}\text { Satisfaction } \\
\text { Level }\end{array}$} & \multicolumn{2}{|c|}{ Female } & \multicolumn{2}{c|}{ Male } & Both Gender \\
\cline { 2 - 7 } & $\begin{array}{c}\text { Fre- } \\
\text { quency }\end{array}$ & $\begin{array}{c}\text { Per- } \\
\text { cent }\end{array}$ & $\begin{array}{c}\text { Fre- } \\
\text { quency }\end{array}$ & $\begin{array}{c}\text { Per- } \\
\text { cent }\end{array}$ & $\begin{array}{c}\text { Fre- } \\
\text { quency }\end{array}$ & $\begin{array}{c}\text { Per- } \\
\text { cent }\end{array}$ \\
\hline Outstanding & 10 & 6.45 & 7 & 3.68 & 17 & 4.93 \\
\hline Very Satisfactory & 69 & 44.52 & 68 & 35.79 & 137 & 39.71 \\
\hline Satisfactory & 62 & 40.00 & 96 & 50.53 & 158 & 45.80 \\
\hline Unsatisfactory & 14 & 9.03 & 19 & 10.00 & 33 & 9.57 \\
\hline Total & 155 & 100.00 & 190 & 100.00 & 345 & 100.00 \\
\hline $\begin{array}{c}\text { Mean } \\
\text { (Description) }\end{array}$ & $\begin{array}{c}2 \\
\text { (Satisfactory) }\end{array}$ & \multicolumn{2}{c|}{$\begin{array}{c}3.32 \\
\text { (Satisfactory) }\end{array}$} & $\begin{array}{c}3.38 \\
\text { (Satisfactory) }\end{array}$ \\
\hline $\begin{array}{c}\text { Standard } \\
\text { Deviation }\end{array}$ & \multicolumn{2}{|c|}{0.567} & \multicolumn{2}{|c|}{0.527} & \multicolumn{2}{|c}{0.548} \\
\hline
\end{tabular}

\section{Competence in drafting technology by gender}

Table 4 shows the data on the students' level of competence in Drafting Technology across gender. Both respondents have "satisfactory" rating in

Table 4. Students' level of competence in drafting technology by gender $($ male $=190$, female $=155)$

\begin{tabular}{|c|c|c|c|c|c|c|}
\hline \multirow{2}{*}{$\begin{array}{l}\text { Competencies } \\
\text { in Drafting } \\
\text { Technology }\end{array}$} & \multicolumn{2}{|c|}{ Female } & \multicolumn{2}{|r|}{ Male } & \multicolumn{2}{|c|}{ Both Gender } \\
\hline & Mean & Description & Mean & Description & Mean & Description \\
\hline $\begin{array}{l}\text { Freehand } \\
\text { Drawing and } \\
\text { Lettering }\end{array}$ & 2.66 & Satisfactory & 2.79 & Satisfactory & 2.73 & Satisfactory \\
\hline $\begin{array}{c}\text { Geometric } \\
\text { Construction }\end{array}$ & 2.82 & Satisfactory & 2.87 & Satisfactory & 2.85 & Satisfactory \\
\hline $\begin{array}{l}\text { Orthographic } \\
\text { Drawing }\end{array}$ & 2.76 & Satisfactory & 2.86 & Satisfactory & 2.81 & Satisfactory \\
\hline $\begin{array}{l}\text { Pictorial } \\
\text { Drawing } \\
\end{array}$ & 2.74 & Satisfactory & 2.86 & Satisfactory & 2.81 & Satisfactory \\
\hline $\begin{array}{c}\text { Commercial } \\
\text { Arts } \\
\end{array}$ & 2.48 & $\begin{array}{l}\text { Unsatis- } \\
\text { factory }\end{array}$ & 2.71 & Satisfactory & 2.61 & Satisfactory \\
\hline $\begin{array}{r}\text { Overall } \\
\text { Competence }\end{array}$ & 2.69 & Satisfactory & 2.82 & Satisfactory & 2.76 & Satisfactory \\
\hline
\end{tabular}


Freehand Drawing and Lettering with a mean of 2.73, Geometric Construction 2.85, Orthographic Drawing 2.81 and Pictorial Drawing, with a mean rating of 2.81and Commercial Arts respectively. The grand mean reflects a "satisfactory" rating indicative of same level competence in drafting technology (Table 4). However, the female respondents exhibited unsatisfactory level of competence towards drafting technology in commercial arts. This gives signal that females students are not bent on doing commercial arts in their drafting technology course activities and besides, commercial arts is not given much emphasis in classroom instruction considering that students learning is more focus in manipulative competence/learning as part of their orientation and preparation in the higher field of learning which is civil engineering and or architectural engineering unlike other competencies that is done in a practical experiences of the learner.

\section{Difference on the students' level of competencies in drafting technology}

Table 5 presents the data of the independent sample T-test distribution on the students' level of competencies in drafting technology according to their sex, respondents are both competent in drafting technology. Given the different competencies in Drafting Technology, with an overall $t$-value of 1.307 which is higher than the $\mathrm{p}$-value of 0.192 interpreted as "not significant". This denotes that there is a comparable level of competencies in Drafting Technology between male and female students. The negative assumption saying that there is no substantial dissimilarity between male and female learners in drafting technology is acknowledged. This implies further that, although there is a comparable result on the level of competence between male and female students, the female respondents need to improve their performance towards Drafting Technology especially in Commercial Arts which they have an unsatisfactory rating.

Table 5. T-Test of mean difference between students' gender and their level of competencies in Drafting Technologies

\begin{tabular}{|c|c|c|c|}
\hline $\begin{array}{c}\text { Competencies in Drafting } \\
\text { Technology }\end{array}$ & T-value & P-value & Interpretation \\
\hline $\begin{array}{c}\text { Freehand Drawing and } \\
\text { Lettering }\end{array}$ & 1.276 & 0.203 & Not Significant \\
\hline Geometric Construction & 0.531 & 0.596 & Not Significant \\
\hline Orthographic Drawing & 1.086 & 0.278 & Not Significant \\
\hline Pictorial Drawing & 1.183 & 0.238 & Not Significant \\
\hline Commercial Arts & 2.134 & 0.034 & Not Significant \\
\hline Overall Competence & 1.307 & 0.192 & Not Significant \\
\hline
\end{tabular}




\section{Difference of attitude and work and study habits towards drafting technology}

Table 6 shows the independent sample T-test distribution on the difference of attitude towards drafting technology of students and the difference of study and work habits of students when compared according to their Sex.

As reflected on Table 6, on the attitude towards drafting technology students it indicates a "not significant" interpretation which means the null hypothesis stating that there is no important change between male and female students towards drafting technology and the attitude of the students towards the subject is accepted. While on the study and work habits of students, the significant difference implies that female students have a more favorable study and work habits than their male counterparts. This means that the null hypothesis which says that there is no substantial difference between male and female students in drafting technology and study and work habits of the students is rejected. This also denotes that male respondents need more motivation and encouragement to improve their study and work habits towards on their field of choice.

Table 6. T-Test of mean difference between students' gender and their attitude towards drafting technology and between students' gender and their study and work habits

\begin{tabular}{|c|c|c|c|}
\hline Variable & T-value & P-value & Interpretation \\
\hline $\begin{array}{c}\text { Attitude towards } \\
\text { Drafting Technology } \\
\text { of Students }\end{array}$ & -1.217 & 0.224 & $\begin{array}{c}\text { Not } \\
\text { Significant }\end{array}$ \\
\hline $\begin{array}{c}\text { Study and Work Habits } \\
\text { of Students }\end{array}$ & -2.227 & 0.027 & Significant \\
\hline
\end{tabular}

\section{Conclusion and Recommendations:}

In the light of the study findings, it is concluded that both male and female grade 8 students have good competency level in their drafting technology course, possessed moderately favourable attitudes with satisfactory study and work habits towards drafting technology. The study elucidated vital information on gender disparity issues in the context of drafting technology. It sheds light towards a clearer understanding within the gender sensitive milieu. In the conceivably man's world of drafting technology, females can equitably provide, render services and execute practical skills thereby attain the desired level of productivity comparable with their male counterpart. Both male and female students can fit in the labour domain without one group dominating over the other. The learning process 
encompasses gender issue providing equal opportunity for both gender along diverse processes and skills development approaches. Vocational institutions are expected to train, nurture and develop students' potential regardless whether they are males or females. In essence, the acquisition of skills is open to young men and women whose productivity and training outcomes are expected to strengthen the quality of the labour force. The labour sector is becoming more open to a variety of changes in the labour structure paving way to equal opportunities for men and women recruits.

It is recommended that the government provide and exposed the students to state of the art facilities and instructional materials to hone their knowledge and skills in drafting classes. Parents should pay much attention in monitoring students not only at home but also at school to keep track of the students' academic performance. Similar study should be conducted on the same subject in senior high school.

\section{References:}

1. Abocejo, F.T., Pañares, Z.A., Dotillos, L.T., Diones, L.L., \& Belciña, S.A. (2012). Microfinance program on cooperatives: Realities, benefits and women's participation. CNU Journal of Higher Education Special Issue on Poverty Alleviation, 6(1), 25-39. Retrieved from http://jhe.cnu.edu.ph/index.php/cnujhe/article/view/119

2. Abocejo, F.T., \& Padua, R.N. (2010). An econometric model for determining sustainability of basic education development. $C N U$ Journal of Higher Education, 4(1), 40-53. Retrieved from http://jhe.cnu.edu.ph/index.php/cnujhe/article/view/39

3. Abocot, R. C., \& Añonuevo, R. T. (2015). Gender politics in Edilberto K. Tiempo's to be free: A cultural studies reading. The Normal Lights, 9(1), 31-48. $\quad$ Retrieved from http://po.pnuresearchportal.org/ejournal/index.php/normal lights/article/viewFile/6/3

4. Abocejo, F.T., \& Gubalane, F.K. (2013). Implementation of the Human Anti Trafficking Law in Cebu City, Central Philippines. International Forum Journal, 16(1), 36-48. Retrieved from https://journals.aiias.edu/iforum/article/ view/143

5. Almazan, J. U., Cruz, J. P., Alamri, S. M., Alotaibi-Monahi, S. J., Albougami, A. S. B., Gravoso, R., Abocejo, F. T., Allen, K., \& Bishwajit, G. (2018). Predicting patterns of disaster-related resiliency among older adult typhoon Haiyan survivors. Geriatric Nursing, 39(6), 629-634. doi: 10.1016/j.gerinurse.2018.04.015

6. Alvarez, I. C. C., Ong, M. B., \& Abocejo, F. T. (2017). Learning needs and quality care among family caregivers and elderly patients of Guadalupe, Cebu city, central Philippines. European Scientific 
Journal, 13(24), 356-376. doi: 10.19044/esj.2017.v13n24p356

7. Brym, R. J. \& Lie J., (2017). Sociology: Pop Culture to Social Structure, Third edition, Wadsworth. Retrieved from www.sociologyguiderole.com/gender/theories-of-gender-dif ferences-and-identity.php

8. Bhuiyan, P. (2018). John Dewey and his education philosophy. (2018). Retrieved from http;www.slideshare.net/pranaybhuiyan/educationphilosophy- of-john-dewey

9. Cerbito-Abocot, R. (2018). Prismatic view of gender power relations at the intersection in Linda Ty-Casper's ten thousand seeds. International Forum, 21(1), 20-33. Retrieved from https://journals.aiias.edu/iforum/article/view/342/334

10. Cillo, A. I. I. (2011). Competencies in Drafting Technology in Public Secondary Schools in Tacloban City. Eastern Visayas State University, Unpublished Master's Thesis

11. Cuñado, A. G., \& Abocejo, F. T. (2018). Lesson planning competency of English major university sophomore students. European Journal of Education Studies, 5(8), 395-409. doi: 10.5281/zenodo.2538422

12. De la Rosa, R. (2005). Philippine education in the third millennium: trends, issues and challenges, concerns. Philippines, 6Ns Enterprises.

13. Commission on Higher Education. (2014). Guidelines on the Utilization of the 2014, Department Order 24, series of 2014. Schools Division Program Support Funds for Strengthened Technical and Vocational Education Program (STVEP). Retrieved from www.deped.gov.ph/order s/do-24-s-2014

14. Commission on Higher Education [CHED]. (2009). Additional Curriculum Guidelines for the 282 Technical-Vocational Secondary Schools Effective SY 2009-2010, Department Order 69, series of 2009. Retrieved from www.deped.gov.ph/ order/do-69-s-2009

15. Fernandez, R. C. C., \& Abocejo, F. T. (2014). Child labor, poverty and school attendance: Evidences from the Philippines by region. $C N U$ Journal of Higher Education, 8(1), 114-127. Retrieved from http://jhe.cnu.edu.ph/index.php/cnujhe/article/view/151

16. Carson, T. (2005). Beyond instrumentalism: The significance of teacher identity in educational change Journal of the Canadian Association for Curriculum Studies, 3(2), 1-8. DOI: 10.1.1.521.4888\&rep=rep1\&type $=$ pdf

17. GEMS-CL. (2017). Addressing gender equality issues in schools. Retrieved from www.deped.gov.ph/regions-iii/regional-pressreleases/gems-cl-addressing-gender-equality-issues-schools

18. Hengehold, L., \& Bauer, N. (2017). A companion to Simone de Beauvoir. John Wiley \& Sons, Inc., NJ, USA 
19. Technical Skills and Development Authority. [TESDA] (2012). Gender issues now part of tech-voc. Retrieved from https://www.tesda.gov.ph/News/Details/236

20. Guterres, A. (2017). Goal 5: Achieve gender equality and empower all women and girls. Retrieved from www.un.org/sustainabledevelopment/gender-equality

21. Kalka, K., (2010). A study on the perception and interest of female students about technology education course content and activities at Poynette High School. (Master's Thesis, University of WisconsinStout).

22. Management and Training Corporation. (2010). Principles and Strategies of a Successful TVET Program. MTC, Centerville, Utah

23. Rimando, J.A. (2012). DepEd strengthens techvoc education. Trade Union Congress of the Philippines. Retrieved from http://tucp.org.ph/2012/01/deped-strengthens-techvoc-educa tion/

24. Mikkola, M. (2018). Zalta, E. (Ed.). The Stanford Encyclopedia of Philosophy. Metaphysics Research Lab, Stanford University-via Stanford Encyclopedia of Philosophy.

25. Mckay, S. \& Hornberger, N. (2009). Sociolinguistics and language teaching. New York: Cambridge University Press.

26. Norton, R. E., (2012). UNESCO-UNEVOC TVETipedia. Retrieved from https://unevoc. unesco.org

27. Orosa, R.L. (2014). TUCP supports more women in male-dominated jobs.

Retrieved from www.philstar.com/headlines/2014/07/31/1352355/tucp-supportsmore-women-male-domi nated-jobs

28. Ossai, M. C., (2012). Age and gender differences in study habits: a framework for proactive counselling against low academic achievement. Journal of Educational and Social Research 2(3), 67-73. Retrieved from http://scholar.google.com.ph

29. Government of the Philippines - Republic Act 10533 [GOP-RA 10533], (2013). Enhanced Basic Education Act of 2013. Retrieved from https://www.officialgazette.gov.ph/2013/09/04/ irr-republic-actno-10533/

30. Rimando, A. J. (2012). DepEd strengthens techvoc education. Retrieved from beta.philstar.com/other-sections/education-andhome/2012/01/766679/deped-strengthens-techvoc-education

31. Rodriguez, K. F. R., \& Abocejo, F. T. (2018). Competence vis-à-vis performance of special education pre-service teachers. European Academic Research, 6(7), 3474-3498. Retrieved from http://www.euacademic.org/UploadArticle/3707.pdf

32. Scott, K., Aist, G., \& Hood, D. (2009). Compu Girls: Designing a 
Culturally Relevant Technology Program. Educational Technology, 49(6), 34-39. Retrieved from Education Research Complete database.

33. Syjuco, A. B. (2005). The Philippine Technical Vocational Education and Training (TVET) System. Retrieved from https://www.tesda.gov.ph/uploads/file/Phil\%20TVET\%20system\% 20-\%20syjuco.pdf.

34. TESDA. (2013). New tech-voc curriculum for $\mathrm{K}$ to 12 in place. Retrieved 2017 from www.tesda.gov.ph/News/Details/301

35. United Nations. (2018). About the sustainable development goals, in Sustainable Development Goals. Retrieved from https://www.un.org/sustainabledevelopment/sustaina bledevelopment-goals/

36. Valenzuela, E. P. (2015). International comparison of curriculum, structure, and content of Brunei, Malaysia, Philippines and Singapore. Indonesia: The SEAMEO Regional Center for Educational Innovation and Technology. SEAMEO INNOTECH. Retrieved from http://www.seameo-innotech.org/wpcontent/uploads/2014/01/Brief04-K\%20to\%2012_FINAL.pdf

37. Zalta, E. N. (ed.) (2015). The Stanford Encyclopedia of Philosophy. Metaphysics Research Lab, Stanford University. Retrieved from https://plato.stanford.edu/ 